Research Article

\title{
The Diversity of Echinoderms in Intertidal Zone of Sundak Beach, Gunung Kidul, Yogyakarta, Indonesia
}

Herin Yoga Lesti ${ }^{1}$, Syifa Evilia Maharani ${ }^{1}$, Naila Nabila Rahmani ${ }^{1}$, Bellia Alda Ayu Prasetya ${ }^{1}$, Fania Baeta Roska Khalallia ${ }^{1}$, Ni Made Sri Winasti ${ }^{1}$, Achmad Mustofa Huda ${ }^{1}$, Septi Lutfiatun Nafiah $^{1}$, Rury Eprilurahman ${ }^{2}$

${ }^{1}$ Marine Study Club, Faculty of Biology, Universitas Gadjah Mada

Jl. Teknika Selatan, Sekip Utara, Yogyakarta, 55281, Indonesia

${ }^{2}$ Laboratory of Animal Taxonomy, Faculty of Biology, Universitas Gadjah Mada,

Jl. Teknika Selatan, Sekip Utara, Yogyakarta, 55281, Indonesia

*email: herin.y.|@mail.ugm.ac.id

Keywords:

Diversity

Biodiversity

Echinoderms

Sundak Beach

Submitted: $16 / 04 / 2021$

Revised: 06/05/2021

Accepted: 08/05/2021
Abstract. Indonesia is a maritime country with high diversity of marine biota, which one is from Phylum Echinoderms. Echinoderms are known as biota of marine which is are living on corals, sandy, and on the intertidal zone and deep ocean. The intertidal characteristics of Sundak Beach has a suitable structure to echinodems life because there are many corals, but there is many species has not been identified before. The purpose of this research is to know the diversity of echinoderms phylum on the intertidal zone. Sampling was carried out on August, 24th 2019 with purposive random sampling method along the coastal-line in intertidal zone. The result of this research are identified and classified on the each class. Based on the results, the are found species from Echinodea, Holothuroidea, and Ophiuroidea. Species from Echinoidea are Tripneustes gratilla, Echinometra mathaei, Heterocentrotus trigonarius, Diadema antillarum., and Echinothrix calamaris. Holothuroidea namely Holothuria atra. Ophiuroidea namely Ophiotrix fragilis, Ophiocoma scolopendrina, and Ophiocoma erinaceus. The conclusion from this study is the discovery of five species from class Echinoidea, one species from class Holothuroidea and three species from class Ophiuroidea.

\section{INTRODUCTION}

Indonesia is one of the countries with a high diversity of marine life, one of those is Echinoderms. Echinoderms are marine exlusive organisms that can be found in the intertidal zone to deep-sea areas. The organisms are characterized by pentamer symmetry bodies in adulthood and bilateral symmetry while still in larval form. The regeneration process in Echinoderms includes all parts of the body, including the nervous system, gonads, and germlines (Reich et al. 2015). 
Echinoderms devided into five major classes, namely Asteroidea containing a variety of starfish, Crinoidea which are often referred to as sea lilies, Echinoidea which includes sea urchins, sand dollars, and sea biscuits, Holothuroidea or sea cucumbers, and Ophiuroidea or brittle stars (Wessel 2016). Asteroidea commonly found in tropical Atlantic waters and the Indo-pacific regions. Asteroidea has a central disc as the center of the body and the shape of the body varies from pillow shape to flattendorsoventral (Badger 2012). Organisms of crinoidea can be found in the deep sea only. It has lilies-like form with stalk organ (cirri) used to attach on the substrate (Eleaume et al. 2016). Echinoidea composed of ten double columns of plates; five in ambulacral and five in the alternating interambulacral. This class has a hollow shape composed of internal skeletons. The surface of the body is covered by spines made of calcite (Schultz 2015). Members of the Holothuroidea class have one distinguishing character from other class members, which is the existence of a crown of tentacle surrounds the mouth of the organisms (Burton and Burton 2002). Ophiuroidea is a class of Echinoderms that contain members with flexible arms so those arms can move freely. The five arms (or more) are centered on the central disc (Stohr et al., 2012).

Sundak beach in one of the beaches in Gunung Kidul Regency with a substrate of sand and dead coral. In Sundak beach also found a lot of algae and seagrasses. In dead coral substrates, many marine biota is found, one of them is the member of the Echinoderms. Research on the diversity of members of the Echinoderms phylum has never been done, therefore this study aims to learn more about the diversity of echinoderms on the Sundak beach along with the character of each species found.

\section{METHODS}

\subsection{Study Sites}

The study was conducted in the intertidal zone of Sundak beach, Gunung Kidul Yogyakarta, Indonesia, situated in $8^{\circ}$ 8'49.46"S latitude and 110 $36^{\prime} 28.46^{\prime \prime} \mathrm{E}$ longitude at August 28th 2019. The area is characterized by sandy and coral substrate with various species of algae and some sea grass on it. There were also tourism activities near the beach.

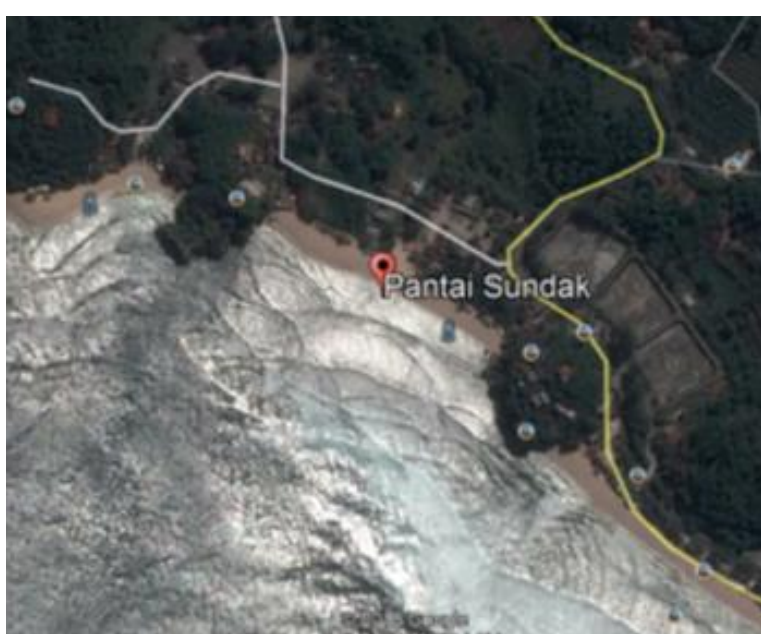

Figure 1. Map of Study Site in Sundak Beach, Gunung Kidul, Yogyakarta, Indonesia

\subsection{Sample Collection}

Samples were collected using purposive sampling with pinset to collect Echinoderms from the coral and hammer to break the coral to collect Echinoderms. Pictures of oral and aboral parts of obtained samples were taken using digital camera for further identification.

\subsection{Sample Preservation}

The obtained samples were preserved by using different procedures according to its class. However, each preservation methods used same chemicals. The 
chemicals were $\mathrm{MgCl} 2$ for relaxation of samples and ethanol for fixation. For class Echinoidea the specimens were soaked in $\mathrm{MgCl} 273 \%$ for 1 minute, then soaked in ethanol $70 \%$ for another 1 minute. In addition, a syringe full of ethanol $70 \%$ were injected into the preoral part of the specimens to quicken the fixation of the internal organs. For class Ophiuroidea, the specimens were soaked in $\mathrm{MgCl} 273 \%$ for 1 minute while its bodies were shaped into comet-like shape, then soaked in ethanol $70 \%$ for 3 minutes. For class Holothuroidea, the specimens were soaked in $\mathrm{MgCl} 25 \%$ for 4 hours, then soaked in ethanol $96 \%$ for 1 day. The specimens were identified by its morphological character like plate structure, body color, and morphometric analysis using taxonomic classification keys as a guide based on Clark and Rowe (1971) and Gosner (1971).

\section{RESULT AND DISCUSSION}

Based on the research, there are seven species of Echinoderms that found in Sundak Beach, Gunung Kidul, Yogyakarta that presented in the table below.

\subsection{Echinoderms in Sundak Beach}

Based on the research, there are seven species of Echinoderms that found in Sundak Beach, Gunung Kidul, Yogyakarta that presented in the table below.

Table 1. Echinoderms in Sundak Beach, Gunung Kidul, Yogyakarta, Indonesia

\begin{tabular}{lll}
\hline Class & Family & Species \\
\hline Echinoidea & $\begin{array}{l}\text { Echinometridae } \\
\text { Diadermatidae } \\
\text { Toxopneustidae }\end{array}$ & $\begin{array}{l}\text { Echinometra mathaei (Gray, 1825) } \\
\text { Heterocentrotus trigonarius (Lamarck, 1816) } \\
\text { Diaderma antillarum (Gray, 1855) }\end{array}$ \\
& Ophiocomidae & $\begin{array}{l}\text { Ophiocoma scolopendrina (Agassiz, 1836) } \\
\text { Ophiocoma erinaceus (Muller \& Troschel, 1842) } \\
\text { Ophiothrix fragilis (Muller, 1759) }\end{array}$ \\
Holothuroidea & Holothuriidae & Holothuria atra (Linnaeus, 1767) \\
\hline
\end{tabular}

\subsection{Echinoidea}

Table 1 shows that there are three families of class Echinoidea found in Sundak Beach; there are Echinometridae, Diadematidae, and Toxopneustidae. The species found in Sundak Beach are Echinometra mathaei, Heterocentrotus trigonarius, Diadema antillarum, Echinothrix calamaris, and Tripneustes gratilla. 


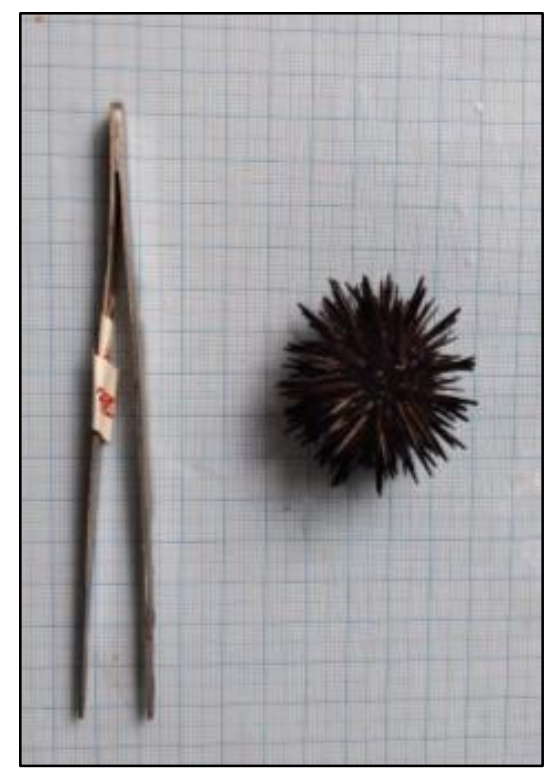

Figure 2. Echinometra mathaei

Echinometra mathaei in english called as rock boring sea urchin. This species is distributed in tropical area, found on reefs in the Indo-Pacific region. Echinometra mathaei is benthic animals occurs along intertidal rocks. It can grows to a diameter of about $5 \mathrm{~cm}$, feeds on algae and small invertebrates. The common spine color of this species is purple or green with purple tips. Its charactherized by a pale ring at the base of each spines (Saravanan et al. 2017). Echinometra mathei contains calcium carbonate sediments between $65 \%$ and $95 \%$ in the fraction of gut. This species is reported to be $55 \%$ water and $40 \%$ spines, with only $5 \%$ of its body being organic matter. Like other echinoideas, $E$. mathaei has morphological plasticity with individuals allocating more resources to various body parts depending on prevailing conditions (Lawrence \& Agatsuma 2007).

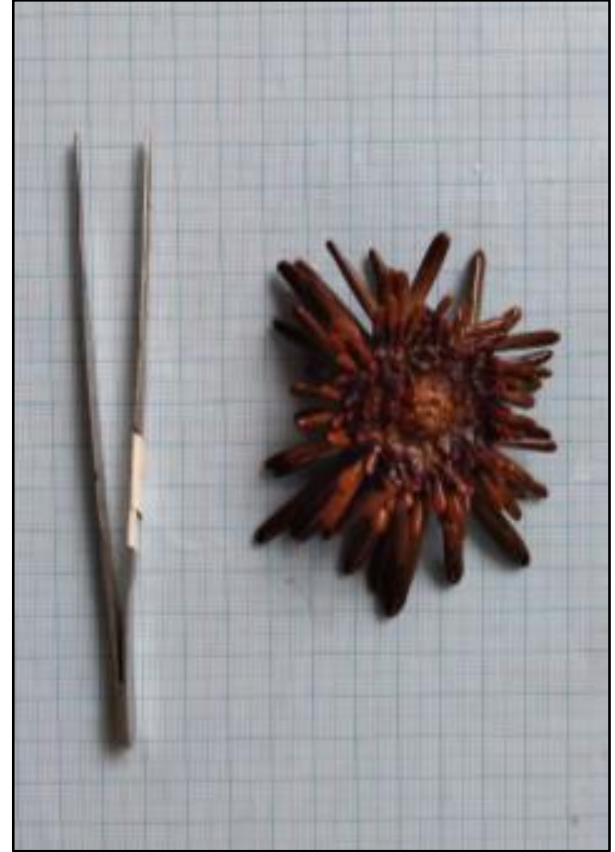

Figure 3. Heterocentrotus trigonarius

Heterocentrotus trigonarius has an ambulacral and interambulacral plate. The ambulacral plates have a single primary tubercle that fills the entire surface of the plate. The interambulacral plates have a large primary tubercle with a very large and thick mammelon in the ambitus. The secondary tubercle attached to the surface of the aboral surface. The peristome at the oral side has an elliptical shape with a buccal curve. In the aboral side, there is a small periproct wih 9 to 14 pore pairs in each plate (Brandt, 1835). 


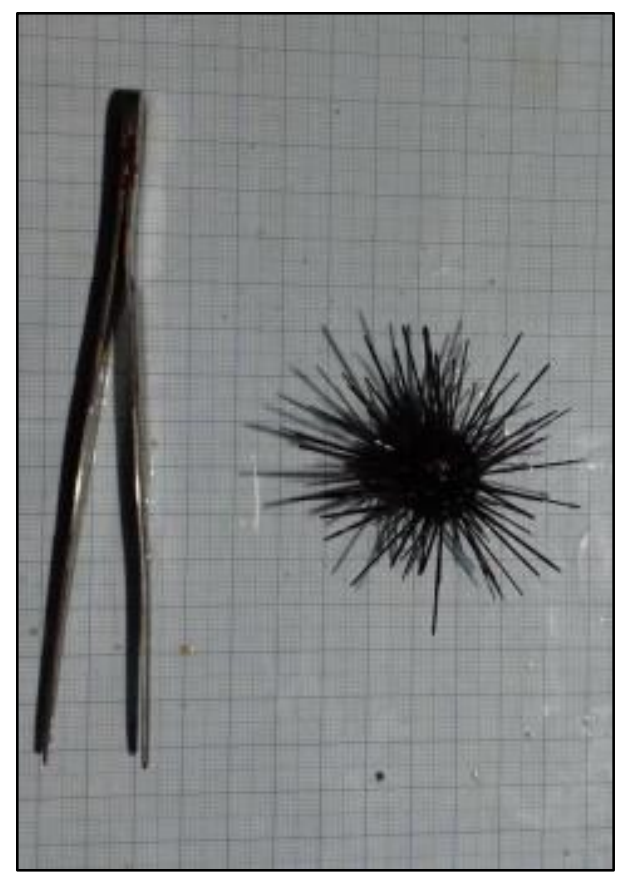

Figure 4. Diadema antillarum

Diadema possess high, almost globular test, inconspicuous globiferous pedicellariae, short spines, usually in white or orange coloration, and in preserved specimens often show conspicuous dark vertical stripe down each interambulacral contrasting with the light ambulacral areas. Diadema antillarum has long and hollow primary spines that are mildly venomous. Tis species has several distinguishing characters on their tests, the most apparent are the presence of five white dots that are strategically located between their ambulacral grooves and bright orange ring around the urchin's periproctal cone, a structure commonly known as "anal bulb" (Clark \& Rowe 1971). The chemical composition of Diadema gonads respectively are water $(76,27 \%$ and $66,86 \%)$, mineral $(1,74 \%$ and $2,09 \%)$, lipid $(5,71 \%$ and $6,89 \%)$, protein $(11,40 \%$ and $12,60 \%)$, and carbohydrate $(4,90 \%$ and 11,58\%) (Tomascik 1997).

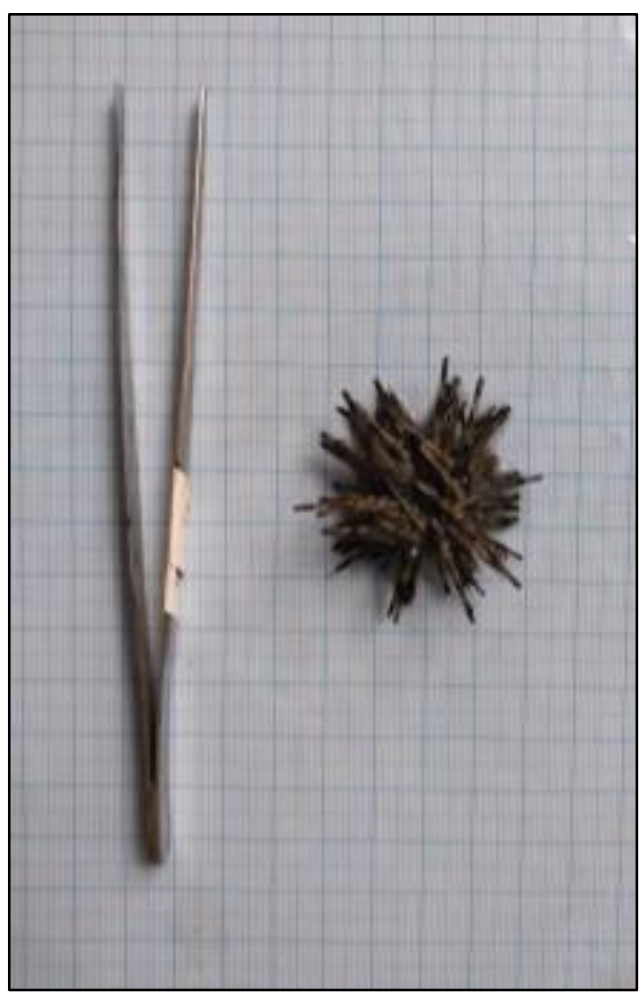

Figure 5. Echinothrix calamaris

Echinothrix calamaris ususally has banded pattern on its primary spines, although some individuals only has black or white primary spines without any banded pattern. The primary spines are long and hollow but the secondary spines are fine and shaped needle-like with backwardlydirectly barb near the tip. The oral side of Echinothrix calamaris is green colored. Unlike Diadema, the spines of Echinothrix calamaris are not veomous, but the chemical composition of their gonad are the same, they are water $(76,27 \%$ and $66,86 \%)$, mineral $(1,74 \%$ and $2,09 \%)$, lipid $(5,71 \%$ and $6,89 \%)$, protein $(11,40 \%$ and $12,60 \%)$, and carbohydrate $(4,90 \%$ and $11,58 \%)$ (Clark \& Rowe 1971; Tomascik,1997). 


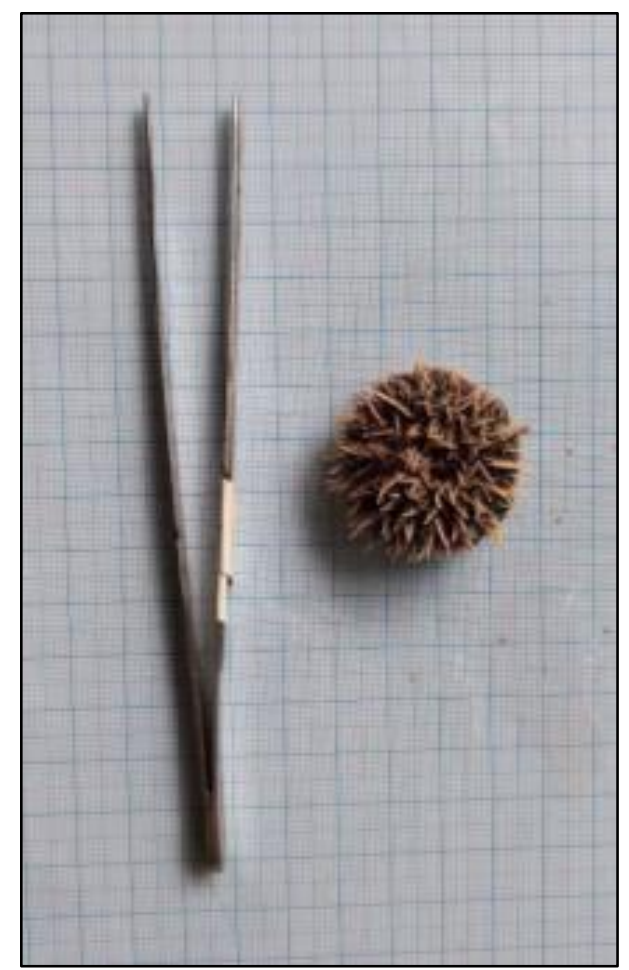

Figure 6. Tripneustes gratilla

Tripneustes gratilla commonly found in the Indo-West Pacific from East Africa to South Sea Islands and from Australia to Southern Japan. It lives in very shallow waters but also found at $75 \mathrm{~m}$. This species occur on a variety of habitats, including seagrass and algae with sand, rock, or coral reef substrate. Tripneustes gratilla is one of the most common sea urchin in intertidal and littoral zone of the coral reefs (Lawrence \& Agatsuma 2007).

\subsection{Ophiuroidea}

Table 1 shows that there are three families of class Ophiuroidea found in Sundak Beach; there are Ophiocomidae and Ophiothricidae. The species found in Sundak Beach are Ophiocoma scolopendrina, Ophiocoma erinaceus, and Ophiothrix fragilis.

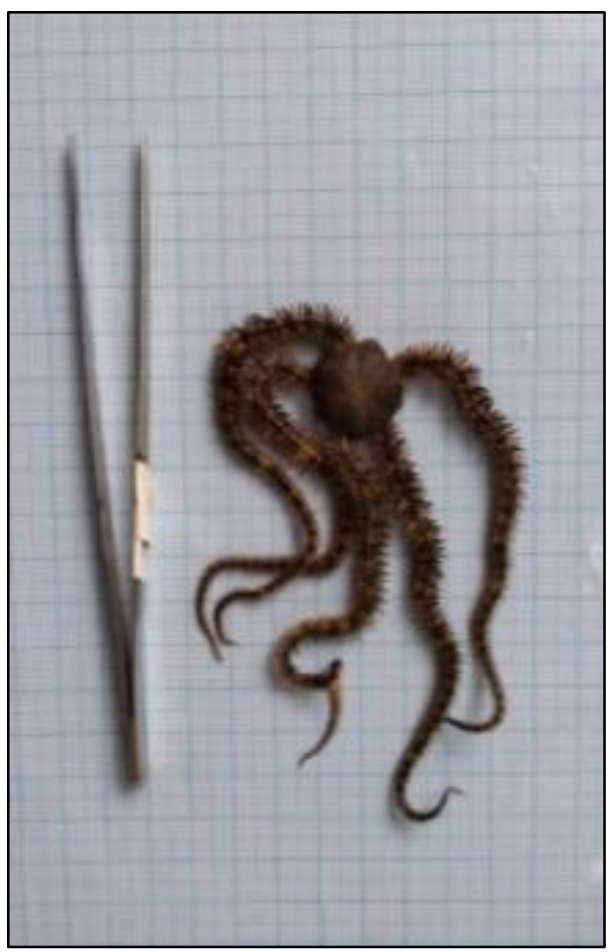

Figure 7. Ophiocoma scolopendrina

Ophiocoma scolopendrina has a lighter body color on underneath and darker on the upper part of its body. O. scolopendrina takes food using several of its arms by filtration or by sweeping the substrate or surface of water. The unique way of feeding behaviour of this species namely "surface film feeding" (Byrne \& O'Hara 2017; Magnus 1967, Jones \& Endean 1976). The main food source of $O$. scolopendrina is particles or material suspended in the sea and also bacteria attached to the sediment. Thus, this species has an important role in the tropodynamics of coral reefs, this species can be decomposers, major producers and highlevel consumers. Ophiocoma scolopendrina in general has a disc granulation coarse, 36 granules/mm length, uppermost arm spines usually thickened and cigarshaped or cylindrical, rarely tapering, the longest averaging 0.2-3 times the segment length but sometimes exceeding 3 times, often no more than four arm spines basally, even at 
diameters $>20 \mathrm{~mm}$. Color paler on the underside, variegated or sometimes uniformly dark above (Clark \& Rowe 1971).

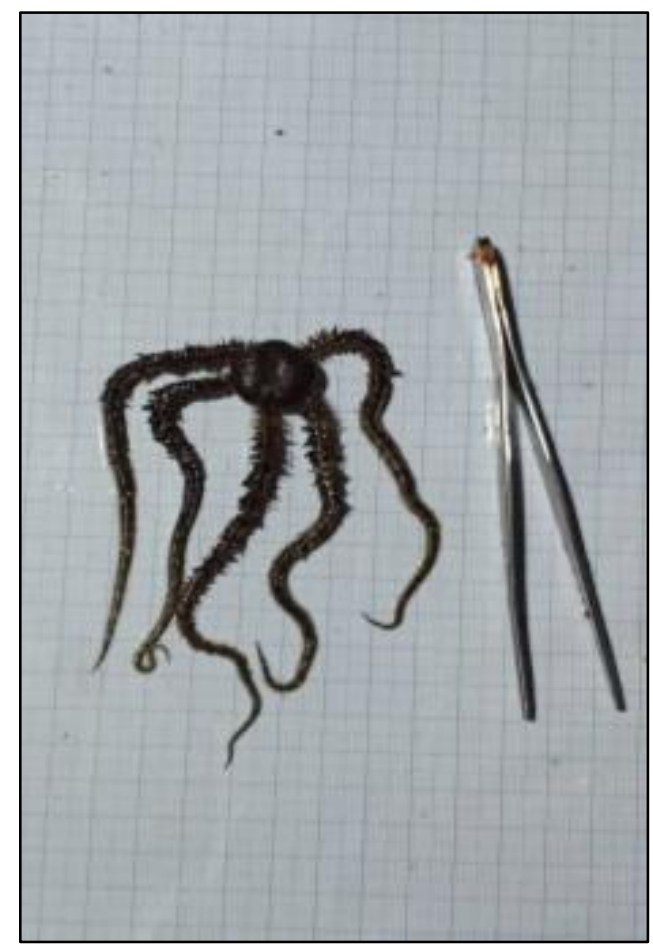

Figure 8. Ophiocoma erinaceus

Ophiocoma erinaceus has almost similar characters with $\mathrm{O}$. scolopendrina. $\mathrm{O}$. erinaceus is often found in deeper water in coral heads (Sloan et al. 1979). O. erinaceus inhabit coral heads, and a range of other species live under coral rubble and clumps of the green alga Halimeda. Thia species has ability to change its colour (Byrne \& O'Hara 2017). Diagnostic characters of $O$. erinaceus are two tentacle scales, colour uniformly dark, above, and below, uppermost arm spines usually cylindrical or cigar-shaped, sometimes (some specimens of $O$. erinaceus) somewhat clavate but then alternate oones on each side of the arm are so modified; arm spines not banded though sometimes spotted; usually two tentacle scales, sometimes only one beyond the basal segments (Clark \& Rowe 1971).

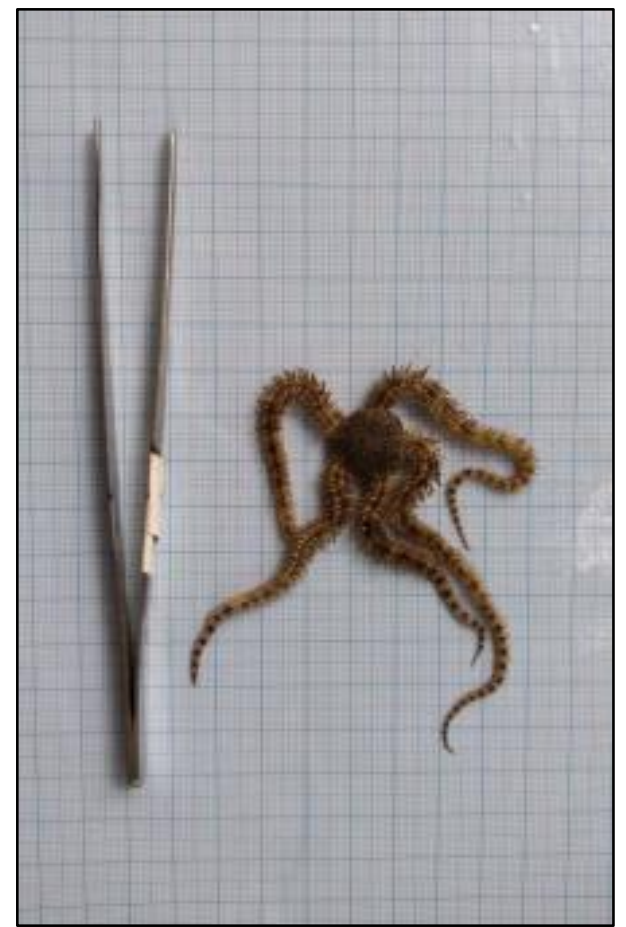

Figure 9. Ophiothrix fragilis

Ophiotrix fragilis have the central disc $1 \mathrm{~cm}$ in diameter with the five arms, which about five times as long. The disc is clothed in five rays of spines radiating from a spiny centre. Between these five pairs of triangular plates; each pair forms a heartshaped pattern. The slender tapering arms are quite distinct from the disc and are covered with overlaping scales. The dorsal arm plates are naked with a longitudinal keel. Each arm segment bears seven glass $y$, toothed spines. The arms are extremely fragile and are easily shed either whole or in pieces. This pieces is extremely variable on colouration like violet, purple, red, yellow or grey, the most often in ared colour with the arms in grey or pink bands (Santhanam et al. 2019) .

\subsection{Holothuroidea}

Table 1 shows that there are three families of class Holothuroidea found in Sundak Beach; there is Holothuriidae. The 
species found in Sundak Beach is Holothuria atra.

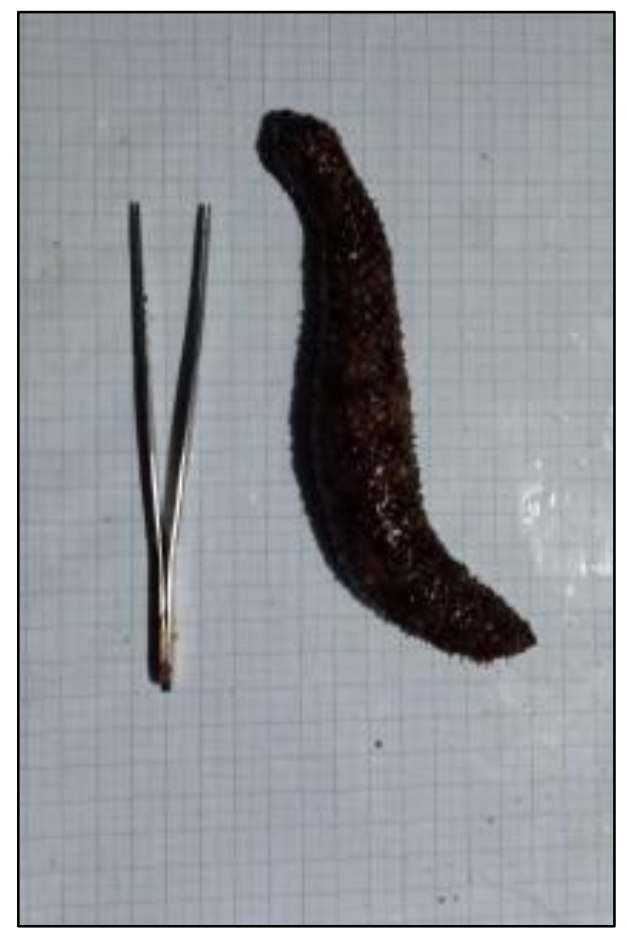

Figure 10. Holothuria atra

Holothuroids or known as sea cucumbers are an abundant and diverse marine invertebrates group. Occur in benthic environments from the intertidal to the deepest ocean zone and constitute $>90 \%$ of the biomass. Most Holothuroids are under $20 \mathrm{~cm}$ in length (Kerr \& Kim 2001). Holothuria atra is the most abundant sea cucumber species in Indo-Pacific region (Bakus 1973; Rowe \& Doty 1977; Aziz 1995; Massin 1996; Setyastuti 2014). It is not only common on sandy beach but also at any type of substrate and coral reef ecosystem (Aziz 1995; Setyastuti 2014). Their color in general is black and usually its body covered with sands (Bakus 1973; Rowe \& Doty 1977; Aziz 1995; Setyastuti 2014). H. atra has slightly a low body temperature (Aziz 1995; Setyastuti 2014). $H$. atra is an omnivore, consuming detritus, uneaten food, and algae in the substrate. It ingests sand grains, digests the nutrient, and then expels sand pellets both in day and night time (Bakus 1973; Setyastuti 2014).

\section{CONCLUSION}

Based on this study, there are nine species of Echinodermata found in the intertidal zone of Sundak Beach. There are Tripneustes gratilla, Echinometra mathaei, Heterocentrotus trigonarius, Diadema antillarum, ,Echinotrix calamaris, Ophiothrix fragilis, Holothuria atra., Ophiocoma scolopendrina, Ophiocoma erinaceus, and Ophiotrix fragilis.

\section{References}

Aziz, A. 1995. Beberapa Catatan tentang Teripang Bangsa Aspidochirotida. Oseana. 20(4):11-23

Badger, J. H. 2012. Global diversity and Phylogeny of the Asteroidea (Echinodermata). PLoS ONE. 7(4): 122.

Bakus, G.J. 1973. The biology and ecology of tropical holothurians. In: Jones, O.A. and R. Endean (eds.). Biology and Geology of coral reefs. Academic Press. New York. pp.325-367.

Burton, M. and Burton, R. 2002. International Wildlife Encyclopedia. Tarrytown: Marchall Cavendish Corporation. p 2276.

Byrne, M and O'Hara, T.D. 2017. Australian Echinoderms: Biology, Ecology and Evolution. CSIRO Publishing. Clayton South, Australia. 38: 326-327.

Clark AM and Rowe FWE, 1971. Monograph of shallow-water Indo-West Pacific echinoderms. The British Museum Publication (Natural History), 690:1-238.

Clark, A. M., Rowe, .W. E. "Monograph of shallowwater Indo-West Pacific 
echinoderms". The British Museum Publication (Natural History), 1971, pp : 1- 238.

Eleaume, M., Schories, D., Kohlberg, G. 2016. Feather Stars, Crinoidea. In: Schories and Kohlberg. Marine Wildlife King George Island Antartica. Dirk Schories Publication, Rostock, p. 212.

Gosper, L. 1971. Guide to identification of marine and estuarine invertebrate. John Wiley and Sons Inc., Canada. Jones and Endean (ed.). 1976. Biology and Geology of Coral Reefs Vol.III Biology 2. Academic Press New York. Pp. 107-108.

Kerr, A.M. and Kim, J. 2001. Phylogeny of Holothuroidea (Echinodermata) inffered from morphology. Zoological Journal of the Linnean Society. 133: 63-81.

Lawrence, J. M. \& Agatsuma, Y. 2007. Ecology of Tripneustes. In: Lawrence, J. M. Edible Sea Urchins: Biology and Ecology. 2nd Edition. Elsevier, USA, pp. $297-305,499-500$.

Magnus, D.B.E. 1967. Ecological and ethological studies and experiments on the echinoderms of the Red Sea.II.Heterometra savignyi, Stud. trop. Oceanogr. 5:644-650.

Massin, C. 1996. Result of the Rhumpius Biohistoritical Expedition to Ambon (1990). Part.4. The Holothurioidea (Echinodermata) Collected at Ambon during the Rumphius Biohistorical Expedition. Zoologische Verhandelingen. 307:18- 19.

Reich, A., Dunn, C., Akasaka, K., and Wessel, G. 2015. Phylogenomic Analyses of Echinodermata Support the Sister Groups of Asterozoa and Echinozoa. PLoS ONE. 10(3): 1-11.

Rowe, F.W.E. and J.E. Doty. 1977. The shallowwWater Holothurians of Guam. Micronesica. 13(2):217-250.
Santhanam, R., Ramesh S. and David, S.R.N. Biology and Ecology of Pharmaceutical Marine Life:

Echinoderms. Florida: CRC Press. pp. 176.

Saravanan, R., Johnson, B \& Edward, L. L. 2017. Echinometra mathaei (Blainville, 1825). In: Ranjan, R., Mutkha, M., Ghosh, S., Gopalakrishnan, A., Gopakumar, G. and Joseph, I. Prioritized Species for Mariculture in India. ICAR-CMFRI, Kochi, p. 440.

Schultz, H. A. G. 2015. Handbook of Zoology: Echinoidea. Hemdingen: Walter de Guyter.

Setyastuti, A. 2014. Echinodermata, Holothuria atra, in Intertidal Seagrass Bed Off The Bama Beach, Baluran National Park, East Java, Indonesia. Jurnal IImu dan Teknologi Kelautan Tropis. 6: 31-39.

Sloan, N.A., Clark, A.M. \& Taylor, J.D. 1979. The echinoderms of Aldabra and their habitats. Bull. Br. Mus. Nat. Hist. (Zool) 37: 81-128.

Stohr, S., O'Hara, T. D., and Thuy, B. 2012. Global diversity of Brittle Stars (Echinodermata: Ophiuroidea). PLoS ONE 7(3): 31940.

Tomascik, T. 1997. The ecology of the Indonesian seas (Part 2). Tuttle Publishing, pp. 878-879

Wessel, G. M. 2016. 6 Diversity in Mechanisms of Germ Line Formation. In P. M. Wassarman [ed]. Essays on Developmental Biology Part 2. London: Elsevier. p 563. 